\title{
Review \\ The biological and clinical importance of the 'new generation' cytokines in rheumatic diseases
}

\author{
Cem Gabay ${ }^{1}$ and lain B Mclnnes ${ }^{2}$
}

\author{
1Division of Rheumatology, University Hospitals of Geneva \& Department of Pathology-Immunology, University of Geneva Medical School, 26 Avenue \\ Beau-Séjour, 1211 Geneva 14, Switzerland \\ 2Division of Immunology, Infection and Inflammation, Glasgow Biomedical Research Centre, University of Glasgow, Scotland, UK
}

Corresponding author: Cem Gabay, cem.gabay@hcuge.ch

Published: 19 May 2009

This article is online at http://arthritis-research.com/content/11/3/230

(c) 2009 BioMed Central Ltd
Arthritis Research \& Therapy 2009, 11:230 (doi:10.1186/ar2680)

\begin{abstract}
A better understanding of cytokine biology over the last two decades has allowed the successful development of cytokine inhibitors against tumour necrosis factor and interleukin (IL)-1 and IL-6. The introduction of these therapies should be considered a breakthrough in the management of several rheumatic diseases. However, many patients will exhibit no or only partial response to these therapies, thus emphasising the importance of exploring other therapeutic strategies. In this article, we review the most recent information on novel cytokines that are often members of previously described cytokine families such as the IL-1 superfamily (IL-18 and IL-33), the IL-12 superfamily (IL-27 and IL-35), the IL-2 superfamily (IL-15 and IL-21), and IL-17. Several data derived from experimental models and clinical samples indicate that some of these cytokines contribute to the pathophysiology of arthritis and other inflammatory diseases. Targeting of some of these cytokines has already been tested in clinical trials with interesting results.
\end{abstract}

\section{Introduction}

Cytokines mediate a wide variety of immunologic actions and are key effectors in the pathogenesis of several human autoimmune diseases. In particular, their pleiotropic functions and propensity for synergistic interactions render them intriguing therapeutic targets. Single-cytokine targeting has proven useful in several rheumatic disease states, including rheumatoid arthritis (RA), psoriatic arthritis (PsA), and across the spectrum of spondyloarthropathies. Strong pre-clinical and clinical evidence implicates tumour necrosis factor-alpha (TNF- $\alpha$ ) and interleukin (IL)- 6 as critical cytokine effectors in inflammatory synovitis. However, non-responders or partial clinical responders upon TNF blockade are not infrequent and disease usually flares up upon discontinuation of treatment. Registry datasets confirm gradual attrition of patients who do reach stable TNF blockade. Crucially, clinical remission is infrequently achieved. Thus, considerable unmet clinical needs remain. This has provoked considerable enterprise in establishing the presence and functional activities of novel cytokines in the context of synovitis. In this short review, we consider the biology and relevant pathophysiology of several novel cytokines present and implicated in synovial processes.

\section{Novel interleukin-1-related cytokines}

The first members of the IL- 1 family of cytokines included $\mathrm{IL}-1 \alpha, \mathrm{IL}-1 \beta, \mathrm{IL}-1$ receptor antagonist (IL-1Ra), and IL-18. Seven additional members of the IL-1 family of ligands have been identified on the basis of sequence homology, threedimensional structure, gene location, and receptor binding $[1,2]$. A new system of terminology has been proposed for the IL- 1 cytokines such that IL- $1 \alpha$, IL-1 $\beta$, IL-1Ra, and IL-18 become IL-1F1, IL-1F2, IL-1F3, and IL-1F4, respectively. The new IL-1 cytokines are termed IL-1F5 through IL-1F11, the latter representing IL-33. IL-1F6, IL-1F8, and IL-1F9 are ligands for the IL-1R-related protein 2 (IL-1Rrp2), requiring the co-receptor IL-1RAcP for activity, and IL-1F5 may represent a receptor antagonist of IL-1Rrp2.

ACR50 = American College of Rheumatology 50\% improvement; ACR70 = American College of Rheumatology $70 \%$ improvement; ClA $=$ collagen-induced arthritis; COX2 = cyclooxygenase 2; DMARD = disease-modifying anti-rheumatic drug; EAE = experimental autoimmune encephalomyelitis; ERK = extracellular-regulated kinase; FLS = fibroblast-like synoviocyte; G-CSF = granulocyte colony-stimulating factor; IFN- $\gamma=$ interferon-gamma; IL = interleukin; IL-1Ra = interleukin-1 receptor antagonist; IL-1Rrp2 = interleukin-1 receptor-related protein 2; IL-18BP = interleukin-18-binding protein; JAK = Janus kinase; JNK = c-jun N-terminal kinase; MAPK = mitogen-activated protein kinase; MIP = macrophage inflammatory protein; $\mathrm{MMP}=$ matrix metalloproteinase; MyD88 = myeloid differentiation 88; NF- $\mathrm{kB}=$ nuclear factor-kappa-B; NK = natural killer; NKT = natural killer $\mathrm{T} ; \mathrm{NO}=$ nitric oxide; $\mathrm{PR} 3=$ proteinase $3 ; \mathrm{PsA}=$ psoriatic arthritis; $\mathrm{RA}=$ rheumatoid arthritis; RANKL = receptor activator of nuclear factor-kappa-B ligand; ROR $\gamma \mathrm{T}=$ retinoic acid-related orphan receptor-gamma-T; SEFIR $=\mathrm{SEF}$ (similar expression to fibroblast growth factors)/interleukin-17 receptor; SLE = systemic lupus erythematosus; STAT = signal transducer and activator of transcription; TCR $=$ T-cell receptor; TGF- $\beta=$ transforming growth factor-beta; TIR $=$ Toll-like receptor/interleukin-1 receptor; TLR $=$ Toll-like receptor; TNF $=$ tumour necrosis factor; TRAF $=$ tumour necrosis factor receptor-associated factor; $\mathrm{T}_{\text {reg }}=$ regulatory $\mathrm{T}$. 


\section{Potential functions of interleukin-1Rrp2-binding cytokines}

The new IL-1 family members, IL-1F5, IL-1F6, IL-1F8, and IL-1F9, were identified by different research groups on the basis of sequence homology, three-dimensional structure, gene location, and receptor binding [3-8]. These new ligands share $21 \%$ to $37 \%$ amino acid homology with IL-1 $\beta$ and IL-1Ra, with the exception of IL-1F5, which has $52 \%$ homology with IL-1Ra, suggesting that IL-1F5 may be an endogenous antagonist. IL-1F6, IL-1F8, and IL-1F9 bind to IL-1Rrp2 and activate nuclear factor-kappa-B (NF- $\mathrm{KB}$ ), c-jun $\mathrm{N}$-terminal kinase (JNK), and extracellular-regulated kinase $1 / 2$ (ERK1/2) signalling pathways, leading to upregulation of IL-6 and IL-8 in responsive cells $[5,9,10]$. Recruitment of IL-1RAcP is also required for signalling via IL-1Rrp2 [9]. These cytokines seem to induce signals in a manner similar to IL-1, but at much higher concentrations (100- to 1,000fold), suggesting that the recombinant IL-1F proteins used in all previous studies lack post-translational modifications that might be important for biologic activities of the endogenous proteins.

Transgenic mice overexpressing $\mathrm{IL}-1 \mathrm{~F} 6$ in keratinocytes exhibit inflammatory skin lesions sharing some features with psoriasis [11]. This phenotype was completely abrogated in IL-1Rrp2- and IL-1RAcP-deficient mice. In contrast, the presence of IL-1F5 deficiency resulted in more severe skin lesions, suggesting that IL-1F5 acts as a receptor antagonist. Expressions of IL-1Rrp2 and IL-1F6 were also increased in the dermal plaques of psoriasis patients, and IL-1F5 was present throughout the epidermis (including both plaques and non-lesional skin), suggesting a possible role for these new IL-1 family members in inflammatory skin disease [11].

IL-1F8 mRNA is present in both human and mouse inflamed joints. Human synovial fibroblasts and human articular chondrocytes expressed IL-1Rrp2 and produced pro-inflammatory mediators in response to recombinant IL-1F8. IL-1F8 mRNA expression was detected in synovial fibroblasts upon stimulation with pro-inflammatory cytokines such as IL- 1 and TNF- $\alpha$. Primary human joint cells produced pro-inflammatory mediators such as IL-6, IL-8, and nitric oxide (NO) in response to a high dose of recombinant IL-1F8 through IL-1Rrp2 binding. However, it is still unclear whether IL-1F8 or IL-1Rrp2 signalling is involved in the pathogenesis of arthritis [10].

\section{Interleukin-33 and the T1/ST2 receptor}

IL-33 (or IL-1F11) was recently identified as a ligand for the orphan IL-1 family receptor T1/ST2. IL-33 is produced as a $30-k D a$ propeptide [12]. The biologic effects of IL-33 are mediated upon binding to T1/ST2 and the recruitment of IL-1RAcP, the common co-receptor of IL- $1 \alpha$, IL-1 $\beta$, IL-1F6, IL-1F8, and IL-1F9 (Figure 1). Cell signals induced by IL-33 are similar to those of $\mathrm{IL}-1$ and include ERK, mitogenactivated protein kinase (MAPK) p38 and JNK, and NF-KB activation [13].
Interestingly, pro-IL-33 has been described previously as a nuclear protein, NF-HEV (nuclear factor-high endothelial venule), and thus exhibited a subcellular localisation similar to that of the IL-1 $\alpha$ precursor [14]. Like pro-IL-1 $\alpha$, nuclear pro-IL-33 appeared to exert unique biologic activities independent of cell surface receptor binding [14-16]. The T1/ST2 receptor exists also as a soluble isoform (sST2) (obtained by differential mRNA processing) that acts as an antagonistic decoy receptor for IL-33 [17]. Serum concentrations of SST2 are elevated in patients suffering from various disorders, including systemic lupus erythematosus (SLE), asthma, septic shock, and trauma $[18,19]$.

\section{Interleukin-33 and T1/ST2 signalling in inflammation and arthritis}

IL-33 and T1/ST2 signalling have been described to exert both pro-inflammatory or protective effects according to the models examined. T1/ST2 was shown to negatively regulate Toll-like receptor (TLR)-4 and IL-1RI signalling by sequestrating the adaptor molecules myeloid differentiation 88 (MyD88) and Mal [20]. Administration of sST2 also reduced lipopolysaccharide (LPS)-induced inflammatory response and mortality [21]. Soluble ST2 has been described to exert anti-inflammatory effects in two different models of ischaemia-reperfusion injury [22,23]. In apolipoprotein Edeficient mice fed with a high-lipid diet, an experimental model of atherosclerosis, IL-33, markedly reduced the severity of aortic lesions via induction of Th2 responses such as IL-5. In contrast, the administration of SST2 led to opposite results, with significantly increased atherosclerotic plaques [24].

Mast cells have been recognised as important mediators of the pathogenesis of arthritis [25,26], suggesting a role for IL-33-mediated mast cell activation in joint inflammation. Indeed, the administration of SST2 decreased the production of inflammatory cytokines and the severity of collagen-induced arthritis (CIA) [27]. Mice deficient in ST2 had an attenuated form of CIA, which was restored by the administration of IL-33 in ST2-deficient mice engrafted with wild-type mast cells, suggesting that the effects of IL-33 may be mediated by the stimulation of mast cells [28]. IL-33 is present in endothelial cells in normal human synovial tissue and its expression is also detected in synovial fibroblasts and $\mathrm{CD}^{2} 8^{+}$cells in the rheumatoid synovium. $\mathrm{IL}-1 \beta$ and TNF- $\alpha$ induced the production of IL-33 by synovial fibroblasts in culture. IL-33 mRNA expression increased in the paws of mice with CIA during the inflammatory early phase of the disease. Administration of neutralising anti-ST2 antibodies reduced the severity of CIA and the production of interferon-gamma (IFN- $\gamma$ ) by lymph node cells stimulated ex vivo [29]. Taken together, these findings indicate that IL-33 plays a role in the pathogenesis of arthritis and therefore may constitute a potential target for future therapy in RA. 


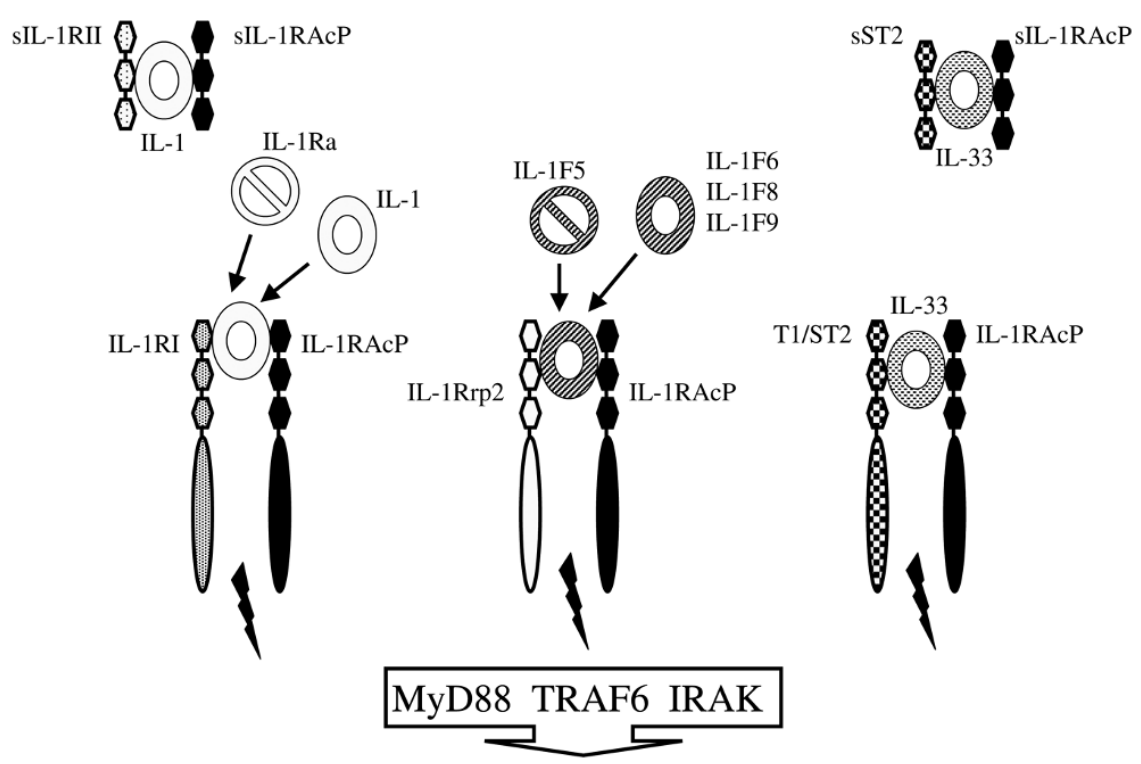

NF-kB, ERK1/2, JNK, p38 MAPK

IL-1RAcP is the common co-receptor. Several members of the IL-1 family of cytokines, including IL-1 (IL-1F1 and IL-1F2), IL-1F6, IL-1F8, IL-1F9, and IL-33 (IL-1F11), bind to their specific cell surface receptors, including IL-1RI, IL-1Rrp2, and T1/ST2, but use IL-1RAcP as a common coreceptor. All of these cytokines stimulate common intracellular signalling events. IL-1RAcP is ubiquitously expressed, whereas the other IL-1 receptors are more selectively expressed in different cell types. Two receptor antagonists, IL-1Ra and IL-1F5, inhibit the biologic activities of the ligands IL-1 and IL-1F6, IL-1F8, and IL-1F9, respectively. In addition, soluble IL-1RAcP inhibits the effect of IL-1 and IL-33 when present in combination with their specific soluble receptors, including IL-1RII and SST2. ERK 1/2, extracellular-regulated kinase 1/2; IL, interleukin; IRAK, interleukin-1 receptor-associated kinase; JNK, c-jun N-terminal kinase; MAPK, mitogen-activated protein kinase; MyD88, myeloid differentiation 88; NF-KB, nuclear factor-kappa-B; TRAF6, tumour necrosis factor receptor-associated factor 6 .

\section{Other interleukin-1 homologues}

Human IL-1F7 gene was identified as a member of the IL-1 family by DNA sequence homology and was mapped on chromosome 2 in the cluster of other IL-1 genes [30]. However, despite extensive database researches, no murine ortholog of IL-1F7 has been found. Five different variants of IL-1F7 (IL-1F7a to IL-1F7e) have been described. IL-1F7b can interact with IL-18-binding protein (IL-18BP) and enhanced its inhibitory effect on IL-18 activities [31]. However, despite this finding, the potential role of IL-1F7b or other isoforms has not been examined in experimental models of inflammation or arthritis so far. The IL-1F10 gene locus was mapped to human chromosome 2. Recombinant IL-1F10 protein binds to soluble IL-1RI, although the binding affinity of this novel IL-1 family member is lower than those of IL-1Ra and IL-1 $\beta$ [32]. However, the significance of this interaction is not clear. The biologic function of IL-1F10 in vivo is unknown.

\section{Interleukin-18 and downstream inducible genes - interleukin-32}

Previously known as IFN- $\gamma$-inducing factor, IL-18 originally was identified as an endotoxin-induced serum factor that stimulated IFN- $\gamma$ production by murine splenocytes and now is recognised to be a member of the IL-1 superfamily; interestingly, it exhibits closest sequence homology to IL-33 within the superfamily [33]. Commensurate with a proposed role in a variety of early inflammatory responses, IL-18 has been identified in cells of either haemopoietic or nonhaemopoietic lineages, including macrophages, dendritic cells, Kupffer cells, keratinocytes, osteoblasts, adrenal cortex cells, intestinal epithelial cells, microglial cells, and synovial fibroblasts [33-38]. IL-18 is produced as a $24-\mathrm{kDa}$ inactive precursor that is cleaved by $\mathrm{IL}-1 \beta$-converting enzyme (caspase-1) to generate a biologically active mature $18-\mathrm{kDa}$ moiety $[39,40]$. This cleavage takes place via inflammasome assembly and therefore cardinal, ASC, and NALP3 are implicated in IL-18 regulation. Further studies implicate proteinase 3 (PR3) as an extracellular-activating enzyme, whereas we recently observed that human neutrophil-derived serine proteases elastase and cathepsin $\mathrm{G}$ also generate novel IL-18-derived species. Factors regulating IL-18 release are unclear; several data implicate extracellular ATP-dependent P2X7 receptor-mediated pathways, together with a novel glycine-mediated pathway for the release of pro-molecule [41]. Like IL-1, cell lysis and cytotoxicity may promote extracellular release, particularly of pro-molecule. Nuclear 
IL-18 expression is also evident in many cell lineages, the biologic significance of which is unclear but of relevance in considering therapeutic targeting.

Mature IL-18 acts via a heterodimer containing an IL-18R $\alpha$ (IL-1Rrp) chain responsible for extracellular binding of IL-18 and a non-binding signal-transducing $\mathrm{IL}-18 \mathrm{R} \beta$ (AcPL) chain [42]. Both chains are required for functional IL-18 signalling. $\mathrm{IL}-18 \mathrm{R}$ is expressed on a variety of cells, including macrophages, neutrophils, natural killer (NK) cells, and endothelial and smooth muscle cells and can be upregulated on naïve T cells, Th1-type cells, and B cells by IL-12. IL-18R $\alpha$ serves as a marker of mature Th1 cells, whereas T-cell receptor (TCR) ligation together with IL-4 downregulates IL-18R. IL-18 neutralisation in vivo results in reduced LPS-induced mortality associated with a subsequent shift in balance from a Th1 to a Th2 immune response. IL-18 signals via the canonical IL-1 signalling pathway, including MyD88 and IL-1 receptor-associated kinase (IRAK), to promote NF- $\kappa B$ nuclear translocation [33]. Thus, IL-18 shares downstream effector pathways with critical immune regulatory molecules such as TLR, which in turn are implicated in regulating IL-18 expression, providing for critical feedback loops in early innate immune regulation, and which can be recapitulated in chronic inflammation to detrimental effect. IL-18 is regulated in vivo via IL-18BP that binds IL-18 with high affinity and by a naturally occurring soluble IL-18R $\alpha$ chain.

IL-18 is present in RA and PsA synovial membrane as both 24-kDa pro-IL-18 and mature IL-18 forms. IL-18 expression is localised in macrophages and in fibroblast-like synoviocytes (FLSs) in situ. IL-18R ( $\alpha$ - and $\beta$-chains) are detected ex vivo on synovial $\mathrm{CD}^{+}$lymphocytes and on $\mathrm{CD} 14^{+}$macrophages and in vitro on FLSs $[34,43,44]$. IL-18BP is also present representing attempted regulation. IL-18 mediates effector biologic activities of potential importance in inflammatory synovitis. Thus, it is a potent activator of Th1 cells but, in context, may also activate Th2 cells, NK cells, and natural killer T (NKT) cells. It induces activation degranulation and cytokine/chemokine release from neutrophils and enhances monocyte maturation, activation, and cytokine release. In addition, it can potentiate the cytokine-mediated activation of $T$ cells and macrophages via enhanced cell-cell interactions. IL-18 reduces chondrocyte proliferation, upregulates inducible NO synthase, stromelysin, and cyclooxygenase 2 (COX2) expression, and increases glycosaminoglycan release. IL-18 further promotes synovial chemokine synthesis and angiogenesis. In contrast, IL-18 inhibits osteoclast maturation through GM-CSF (granulocyte-macrophage colony-stimulating factor) production by $\mathrm{T}$ cells, thereby retarding bone erosion [45]. Suppression of COX2 expression may also be mediated through IFN- $\gamma$ production with consequent effects upon prostanoid-mediated local inflammation. These data clearly indicate that IL-18 and its receptor system are present in inflammatory synovitis and of potential functional importance.
$\mathrm{IL}-18$ targeting in vivo modulates several models of inflammatory arthritis. IL-18-deficient mice on a DBA/1 background exhibit reduced incidence and severity of arthritis associated with modified collagen-specific immune responsiveness. Neutralisation of IL-18 in vivo using specific antibodies or IL-18BP effectively reduces developing and established rodent arthritis in both streptococcal cell wall and CIA models. A feature of both models is suppression not only of inflammation but also of matrix destruction despite the in vitro evidence that IL-18 may be a net bone protective factor and that it may enhance regulatory $T\left(T_{\text {reg }}\right)$ responses if modulated later in the course of these disease models. These data strongly suggest that the net effect of IL-18 expression is proinflammatory, at least in the context of antigen-driven articular inflammation.

Clinical studies to formally test the hypothesis that IL-18 has a pivotal inflammatory role have been performed thus far using recombinant IL-18BP in phase I designs in psoriasis and RA patients [46]. In neither study were efficacious responses reported to our knowledge. The reason for this apparent failure of efficacy is unclear and may reflect intrinsic properties of the inhibitor employed. It could be, however, that the effector function of IL-18 or its downstream signalling pathways is sufficiently redundant in the synovial lesion, analogous to IL-1, so as to render inhibition of limited value. It will be important to seek formal proof of concept using monoclonal antibodies specific for mature IL-18 to properly define the biologic role and therefore therapeutic utility of this cytokine in pathology. A further intriguing approach is to modulate the synthesis and release of IL-18. Whereas the inhibition of caspase-1 using orally bioavailable inhibitors was not successful, there is renewed interest in the capacity of ion channel modifiers in this regard. In particular, inhibition of the P2X7 receptor may provide an opportunity to block not only IL-18 but also IL-1 effector function. Clinical trials are ongoing in RA. Finally, it will be of interest to explore the relevant clinical biology of IL-18 in other rheumatic disease states, not least of which are adult-onset Still disease and SLE since high levels of mature IL-18 are detected in these conditions and the effector biologic profile is plausible and tractable in relevant murine models.

In a search for IL-18-inducible genes, Dinarello and colleagues [47] identified a novel cytokine designated IL-32. IL-32 is constitutively and inducibly expressed by monocytes and by epithelial cells within multiple human inflammatory tissues, and expression has now been described in a variety of pathologies, including RA, chronic obstructive pulmonary disease, asthma, and inflammatory bowel disease [48]. In particular, IL-32 is expressed in RA synovial tissue biopsies, where it correlates closely with disease severity. Although the receptor components are currently unclear, IL-32 likely mediates effector function through activation of NF- $\mathrm{BB}$ and p38 MAPK, leading to the induction of TNF- $\alpha, I L-1, I L-6$, and several chemokines [47]. Human T cells activated with anti- 
CD3 or phorbol myristate acetate/ionomycin express IL-32 $\alpha / \beta / \gamma$. IL-32 is also a potent activator of human monocytes and macrophages in synergy with TLR agonists [49]. However, it remains unclear which isoforms of IL-32 are responsible for the induction of pro-inflammatory cytokines since only IL-32 $\alpha$ and IL-32 $\beta$ can be detected in supernatants of activated primary human T cells by Western blot.

Further studies will be needed to elucidate the signalling pathway(s) for IL-32 to allow development of rational approaches to intervention. Antibodies against functionally active isoforms represent a further logical approach to therapeutic modulation. Much remains to be understood with respect to the extracellular biology of this cytokine. For example, the serine protease PR3 expressed by neutrophils binds and cleaves IL-32 $\alpha$ from a $20-k D a$ protein, forming two cleavage products of 16 and $13 \mathrm{kDa}$. Cleavage of IL-32 by PR3 was also shown to exacerbate the induction of macrophage inflammatory protein (MIP)-2 and IL-8 in mouse RAW264.7 cells. Inhibition of PR3, using serine protease inhibitors, is therefore an attractive potential target. However, further studies using animal models of arthritis will need to be tested to assess the true therapeutic value of PR3 inhibition. In summary, the broad functional activity and expression of IL-32 in a variety of disease states, together with the elegant work thus far performed to elucidate its activities, render it an interesting potential target.

\section{Common $\gamma$-chain signalling cytokines - interleukin-15 and interleukin-21}

IL-15 (14 to $15 \mathrm{kDa})$ is a four- $\alpha$-helix cytokine with structural similarities to IL-2 and was first described in 1994 in normal and tumour tissues and thereafter in RA synovium in 1996 $[50,51]$. IL-15 mRNA is widely expressed in numerous normal human tissues and cell types, including activated monocytes, mast cells, dendritic cells, and fibroblasts [52,53], where it is subject to tight regulation manifest primarily at the translational level. Such regulation is mediated via $5^{\prime}$ UTR (untranslated region) AUG triplets, $3^{\prime}$ regulatory elements, and a further C-terminus region regulatory site. Once translated, secreted IL-15 (48 amino acids) is generated from a long signalling peptide whereas an intracellular IL-15 form localised to non-endoplasmic regions in both cytoplasmic and nuclear compartments derives from a short signalling peptide (21 amino acids) [54,55]. Cell membrane expression is crucial in mediating extracellular function; such expression may be a fundamental property of IL-15 (its sequence contains a theoretic transmembrane domain) or it may arise from membrane formation of complexes with IL-15R $\alpha$, thereby facilitating 'trans' receptor complex formation (see below). IL-15 mediates effector function via a widely distributed heterotrimeric receptor (IL-15R) that consists of a $\beta$-chain (shared with IL-2) and common $\gamma$-chain, together with a unique $\alpha$-chain (IL-15R $\alpha$ ) that in turn exists in eight isoforms [53,56]. IL-15R heterocomplexes are described on T-cell subsets, NK cells, B cells, monocytes, macrophages, dendritic cells, and fibroblasts. Evaluation of the potential for IL-15 responsiveness is complicated by the capacity for trans signalling whereby IL-15-IL-15R $\alpha$ complexes on one cell can bind to IL-15R $\beta \gamma$ chains on adjacent cells [57]. This is of particular importance in identifying IL-15-responsive cells in complex pathologic lesions in which receptor subunits are localised.

The $15 R \alpha \beta \gamma$ complex signals via recruiting Janus kinase (JAK) $1 / 3$ to the $\beta$ - and $\gamma$-chain receptors, respectively. These complexes in turn recruit STAT3 (signal transducer and activator of transcription 3) and STAT5 via $\mathrm{SH} 2$ domains that are tyrosine-phosphorylated, facilitating nuclear translocation to drive downstream gene transcription [53,58,59]. Additional signalling through TRAF2 (TNF receptor-associated factor 2), src-related tyrosine kinases, and Ras/Raf/MAPK to fos/jun activation has been demonstrated. IL-15R $\alpha$ exists as a natural soluble receptor chain with high affinity $\left(10^{11} / \mathrm{M}\right)$ and slow off-rate, rendering it a useful and specific inhibitor in biologic systems.

IL-15-deficient mice exhibit reduced numbers of NK, NKT, $\gamma \delta T$, and CD8 cell subsets commensurate with an important survival anti-apoptotic function for multiple haemopoetic lineages. IL-15 is an activator of NK cells promoting cytokine release and cytotoxic function. Th1 and Th17 cells proliferate and produce cytokine to IL-15 and exhibit prolonged survival, and in B cells, isotype switching and survival are enhanced by IL-15. IL-15 promotes neutrophil activation, cytokine and chemokine release, degranulation, and phagocytic function. Similarly, monocytes and macrophages exhibit activation, increased phagocytic activity, and cytokine production $[60,61]$. Finally, mast cells produce cytokine and chemokine and degranulate to IL-15, operating via an ill-defined, perhaps unique, receptor pathway. IL-15 thus possesses a plausible biologic profile for a role in a variety of inflammatory rheumatic disorders.

$\mathrm{IL}-15$ is present at mRNA and protein levels in RA, PsA, juvenile idiopathic arthritis, and spondyloarthritis synovial membrane and in some sera $[50,51,62-64]$ and is localised in tissue in macrophages, FLSs, and perhaps endothelial cells. Serum IL-15 expression generally does not correlate with disease subsets thus far recognised, nor with disease activity. Expression is maintained in patients in whom an inadequate response to TNF blockade is observed. Spontaneous production of IL-15 by primary RA synovial membrane cultures and by isolated synovial fibroblasts is reported [65]. In explant cultures, tissue outgrowth is dependent upon the presence of T cells, which in turn drives release of IL-15, fibroblast growth factor 1, and IL-17 [66]. Finally, recent intriguing data also implicate IL-15 in early synovial changes in osteoarthritis, suggesting that it may play a hitherto unrecognised role in mediating innate responses in that disease [67].

Effector function of IL-15 in synovium is predicated largely upon its basic biology described above. IL-15 promotes 
T cell/macrophage interactions to drive activation and cytokine release operating mainly via enhanced cognate cell membrane-dependent interactions. Various studies implicate at least CD69, lymphocyte function-associated antigen 1, CD11bm CD40/CD154, and intracellular adhesion molecule 1 in these interactions, although other ligand pairs are likely to be involved. IL-15 operates in synergy with cytokines, including TNF- $\alpha, \mathrm{IL}-18, \mathrm{IL}-12$, and IL-6, thereby creating positive feedback loops to expand synovial inflammation. Similar interactions between $\mathrm{T}$ cells and FLSs with endogenous positive feedback loops have been demonstrated. IL-15 also promotes synovial T-cell migration and survival and is directly implicated in overproduction of synovial IL-17 [50,68]. IL-15 also promotes synovial neutrophil activation and survival, NK cell activation, and synovial fibroblast and vascular endothelial cell survival. The factors that drive synovial IL-15 expression remain unclear. $\mathrm{T}$ cell/macrophage interactions induce IL-15 expression in macrophages. TNF/IL-1-induced FLSs express high levels of IL-15, though rarely in secreted form. Studies of synovial embryonic growth factor expression via the wingless $(W n t) 5$ and frizzled $\left(F_{z}\right) 5$ ligand pair suggest that these ligands can promote IL-15 expression [69].

IL-15 targeting in rodent inflammatory disease models further implicates IL-15 in effector pathology. Recombinant IL-15 accelerates type II CIA (incomplete Freund adjuvant model), whereas administration of soluble murine IL-15 receptor alpha (smlL-15R $\alpha$ ), mutant IL-15 species, or anti-mlL-15 antibody inhibits $\mathrm{CIA}$ in DBA/1 mice. This is associated with delayed development of anti-collagen-specific antibodies (IgG2a) and with reduced collagen-specific T-cell cytokine production, suggesting modulation of adaptive immunity. Finally, shlL-15R $\alpha$ suppresses the development of CIA in a primate model (I.B. Mclnnes, F.Y. Liew, unpublished data). Together, these data clearly indicate that IL-15/IL-15R interactions are important in the development of arthritogenic immune responses in vivo. In addition, any data in other disease states have similarly implicated IL-15 in effector tissue pathology, including in psoriatic and inflammatory bowel disease models.

Clinical studies in humans have been undertaken using two distinct targeting approaches. Mik $\beta 1$ is a monoclonal antibody against IL-2/15R $\beta$ chain that can prevent trans signalling. Studies using this antibody in uveitis, multiple sclerosis, and RA are ongoing; longer-term studies will be required to evaluate the potential of this approach properly since IL-2 blockade may provoke paradoxical autoimmunity. AMG714 is a fully human lgG1 monoclonal antibody that binds and neutralises the activity of soluble and membranebound IL-15 in vitro. AMG714 was administered to patients with RA $(n=30)$ in a 12-week dose-ascending placebocontrolled study. Patients received a randomised, controlled, single dose of AMG714 (0.5 to $8 \mathrm{mg} / \mathrm{kg}$ ) followed by openlabel weekly doses for 4 weeks. IL-15 neutralisation was well tolerated, and improvements in disease activity were observed. However, this study was not placebo-controlled throughout. A dose-finding study in which patients received increasing fixed doses of AMG714 every 2 weeks by subcutaneous injection for 3 months was recently performed. This study differentiated active drug from placebo in clinical composite outcome measures at weeks 12 and 16 but failed to reach its primary endpoint at week 14 . Significant reduction in acute-phase response was achieved within 2 weeks. No significant alterations in the levels of circulating leucocyte subsets, including NK cells and $\mathrm{CD}^{+}$memory $\mathrm{T}$ cells, were observed. The long-term value of this approach, however, is unclear since trials in other inflammatory disease indications have been less encouraging. Other antibodies are under consideration with RA as a primary indication. Studies are awaited. At this stage, therefore, clinical trial data provide useful proof of biologic concept but IL-15 should not be considered a validated clinical target.

IL-21 is another member of the four- $\alpha$-helix family of cytokines which appears to play an important role in the pathogenesis of a variety of rheumatic diseases. IL-21 is a potent inflammatory cytokine that mediates its effects via IL-21R and the common $\gamma$-chain [70]. IL-21 both is a product of and mediates broad effects upon T-cell activation and on NK-cell and NKT-cell maturation and activation. However, the effects of IL-21 on B-cell maturation and on plasma cell development are most remarkable and account for its proposed fundamentally important role in autoantibody-mediated autoimmune processes [71] (Figure 2). IL-21 mediates broad effects beyond B-cell activation. IL-21 promotes T-follicular helper Tcell generation [72]. It preferentially promotes Th17 commitment and expansion [73], acting via IRF-4- and c-mafdependent pathways $[74,75]$. It may also suppress the generation of $T_{\text {reg }}$ cells, further skewing host immune responses to an inflammatory, potentially autoimmune, polarity. Effects beyond the $\alpha \beta T C R$ CD4 T-cell compartment likely exist since IL-21 has been shown to activate human $\gamma \delta \mathrm{T}$ cells ex vivo [76]. Further effector function in innate pathways is proposed based on its capacity to activate NK cells, including cytokine production and cytotoxicity [77].

IL-21 levels are detectable in RA and SLE patient sera and in the synovial tissues of RA patients. Inhibition of IL-21 or gene targeting of IL-21 mediates the suppression of a variety of models, including $\mathrm{CIA}$ and several murine lupus models. Clinical trials directly targeting IL-21 are in pre-clinical planning at this time.

The therapeutic utility of this cytokine superfamily has been further validated by the recent successful introduction of JAK inhibitors in transplant and particularly in RA clinical trials [78]. Thus, inhibitors of JAK3 mediate significant suppression of RA disease activity with a substantial proportion of patients achieving high-hurdle endpoints at ACR50 (American College of Rheumatology $50 \%$ improvement) and ACR70 


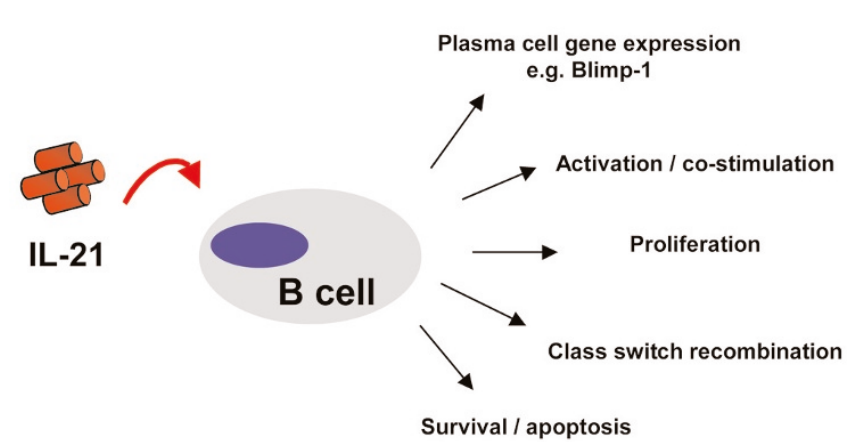

Interleukin-21 (IL-21) is a key inducer of B-cell activation and differentiation and of plasma cell generation. The key activities in the B-cell compartment are depicted.

levels [79]. It is not yet clear to what extent these effects are mediated via JAK3 alone or via off-target effects on other members of the JAK signalling pathways or beyond. Moreover, the toxicity profile of these agents used either alone or in combination with other conventional disease-modifying anti-rheumatic drugs (DMARDs) remains unclear. Immunosuppression-related, haemopoetic, and metabolic effects, some of which are predictable on the basis of pathwayspecific biology, have been observed. Phase III trials across a range of indications are ongoing and their outcomes are awaited with considerable interest.

\section{Recently described interleukin-12 superfamily members - interleukin-27 and interleukin-35}

This cytokine superfamily has expanded recently and is of considerable interest in inflammatory arthritis pathogenesis (Figure 3). Whereas others have reviewed the relevant biology of IL-12 and IL-23 recently and extensively [80,81], we shall consider only novel cytokines of this family. IL-27 is a heterodimeric cytokine consisting of an IL-12p40-related protein, EBI3, and a unique IL-12p35-like protein p28. Early studies suggested that IL-27R-deficient mice exhibit reduced Th1 responses in in vitro and in vivo assays [82,83]. Consistent with these reports, IL-27 neutralisation in one study of rodent adjuvant arthritis suggested the suppression of inflammation. In contrast, other studies demonstrated that IL-27R-deficient mice developed elevated Th17 and enhanced central nervous system inflammation when infected with Toxoplasma gondii or induced for experimental autoimmune encephalomyelitis (EAE), implying that IL-27 was an antagonist of Th17 activity $[84,85]$. IL-27 can inhibit the development of Th17 cells in vitro. Thus, IL-27 may be able to induce Th1-cell differentiation on naïve $C D 4^{+} \mathrm{T}$ cells but is also able to suppress pro-inflammatory Th17 cytokine production. We recently detected IL-27 expression in human RA tissues, including $\mathrm{EBI} 3$ and p28 expression primarily in macrophages, by Western blotting and immunohisto-
Figure 3

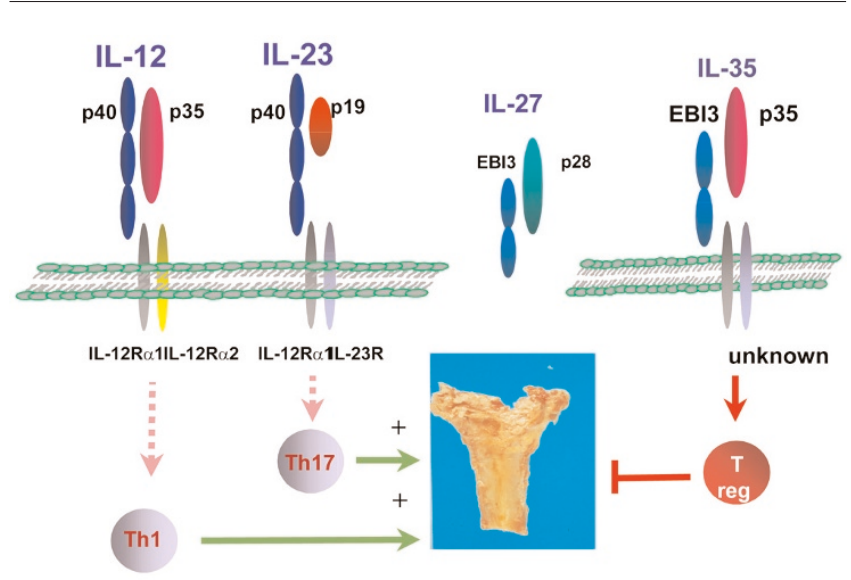

The interleukin (IL)-12 superfamily. This cytokine superfamily contains at least four members: IL-12, IL-23, IL-27, and IL-35. They share peptides as indicated; note that EIB3 shares significant homology with $\mathrm{p} 40$. The key effects on T-cell subsets are depicted, showing IL-12 driving Th1 cells, IL-23 expanding Th1 7 cells, and IL-35 modulating regulatory $T\left(T_{\text {reg }}\right)$ function. It is unclear at this time whether IL-35 is exclusively $T_{\text {reg }}$-derived or whether it can emanate from adjacent cell lineages to promote $T_{\text {reg }}$ function. IL-27 has bimodal function in T-cell regulation dependent upon the maturity and differentiation status of the T cell.

chemistry [86]. We also found that recombinant IL-27 was able to attenuate CIA when administrated at the onset of articular disease. Reduced disease development was associated with downregulation of ex vivo IL-17 and IL-6 synthesis. In contrast, when IL-27 was administered late in disease development, it exacerbated disease progression accompanied by elevated IFN- $\gamma$, TNF- $\alpha$, and IL- 6 production. IL-27 was able to inhibit Th17 differentiation from naïve CD4 ${ }^{+} \mathrm{T}$ cells but had little or no effect on IL-17 production by polarised Th17 cells in vitro.

Very recently, a further novel member of this cytokine family, IL35 , which consists of EBI3 together with $\mathrm{p} 35$, has been described $[87,88]$. Preliminary data indicate that this cytokine is concerned primarily with $T_{\text {reg }}$ effector function, and as such, this may be of considerable interest in the rheumatic disease field. For example, IL-35:Fc fusion protein is able to effectively suppress CIA in DBA/1 mice to a degree similar to etanercept [88]. Such effects are mediated in part via suppression of Th17 responses. However, the presence and indeed functional existence of IL-35 in humans have not yet been proven and remain controversial. Its significance in human autoimmunity, therefore, awaits further detailed characterisation.

\section{Interleukin-17 and interleukin-17-related cytokines \\ Ligands}

IL-17 (or IL-17A) was first cloned in 1993 from an activated mouse T-cell hybridoma by substractive hybridisation and 
Table 1

\begin{tabular}{|c|c|c|c|}
\hline $\begin{array}{l}\text { Ligands } \\
\text { (alternative names) }\end{array}$ & Produced mainly by & Binding receptors & Tissue expression of receptors \\
\hline \multirow[t]{2}{*}{ IL-17 (IL-17A) } & T cells (Th17) & IL-17RA & Widely expressed \\
\hline & & IL-17RC & $\begin{array}{l}\text { Cartilage, synovial tissue, brain, heart, small intestine, kidney, } \\
\text { lung, colon, liver, skeletal muscle, placenta, prostate, low } \\
\text { expression in thymus }\end{array}$ \\
\hline IL-17A/IL-17F & T cells (Th17) & $\begin{array}{l}\text { IL-17RA } \\
\text { IL-17RC }\end{array}$ & \\
\hline IL-17B & $\begin{array}{l}\text { Adult pancreas, small } \\
\text { intestine, stomach }\end{array}$ & IL-17RB & $\begin{array}{l}\text { Several endocrine tissues, liver, kidney, pancreas, testis, brain, } \\
\text { colon, small intestine, not detected in lymphoid organs and } \\
\text { peripheral leucocytes }\end{array}$ \\
\hline IL-17C & Prostate, foetal kidney & Unknown & \\
\hline IL-17D & $\begin{array}{l}\text { Adipose tissue, skeletal } \\
\text { muscle, CNS }\end{array}$ & Unknown & \\
\hline IL-17E (IL-25) & $\begin{array}{l}\text { CNS, kidney, lung, prostate, } \\
\text { testis, adrenal gland, trachea }\end{array}$ & $\begin{array}{l}\text { IL-17RA } \\
\text { IL-17RB }\end{array}$ & \\
\hline IL-17F & T cells (Th17) & $\begin{array}{l}\text { IL-17RA } \\
\text { IL-17RC }\end{array}$ & \\
\hline Unknown & & $\begin{array}{l}\text { IL-17RD (SEF } \\
\text { homologue) }\end{array}$ & $\begin{array}{l}\text { Endothelial cells, kidney, colon, skeletal muscle, heart, salivary } \\
\text { glands, seminal vesicles, small intestine }\end{array}$ \\
\hline Unknown & & IL-17RE & Tumour cell lines \\
\hline
\end{tabular}

CNS, central nervous system; IL, interleukin; SEF, similar expression to fibroblast growth factors.

initially termed CTLA8. The human counterparts exhibit a $63 \%$ amino acid sequence homology with mouse IL-17 and $72 \%$ amino acid identity with a T-lymphocytic herpesvirus, Herpesvirus saimiri [89]. Through database searches and degenerative reverse transcription-polymerase chain reaction, we identified five related cytokines (IL-17B to IL-17F) that share $20 \%$ to $50 \%$ sequence homology with IL-17, which has been termed IL-17A as the founder of a new family of cytokines (Table 1). IL-17A and IL-17F share the highest level of sequence homology (reviewed in [90]). IL-17F is expressed as a disulfide-bound glycosylated homodimer that contains characteristic cystein knot formation. Given the conservation of $\mathrm{IL}-17 \mathrm{~A}$ and $\mathrm{IL}-17 \mathrm{~F}$, it is likely that the two cytokines adopt a similar structure. IL-17A and IL-17F are produced as homodimers primarily by activated CD4 ${ }^{+} \mathrm{T}$ cells (see Th17 cells below) and as IL-17A/IL-17F heterodimers with similar cysteins involved in the disulfide linkage as in homodimeric cytokines [91].

\section{Interleukin-17 receptors and signalling}

The IL-17 receptor family consists of five members: IL-17RA, IL-17RB, IL-17RC, IL-17RD, and IL-17RE (Table 1). Similar to their cognate cytokines, $\mathrm{IL}-17$ receptor complexes are multimeric. IL-17A binds to a receptor complex composed of at least two IL-17RA subunits and one IL-17RC subunit. IL-17A binds to IL-17RA with high affinity. In contrast, IL-17F binds to IL-17RA with low affinity but with a stronger binding affinity to IL-17RC [92]. Recent findings suggest that both
IL-17RA and IL-17RC are necessary for the biologic activity of IL-17A and IL-17F homodimers as well as of IL-17A/IL-17F heterodimers [93]. Recently, it has been shown that soluble IL-17RC can inhibit the activities of both IL-17A and IL-17F in vitro, although concentrations required to inhibit IL-17A are much larger and vary according to cell types. Interestingly, IL-17RC exists as several splicing products, including soluble forms of IL-17RC mRNA, which may serve as natural IL-17A and IL-17F antagonists [94]. IL-17 activates many signalling pathways in common with those of the TLR/IL-1R (TIR) family, including TRAF6 and NF- $\mathrm{BB}$, and MAPK pathways. The identification of a functional domain with similarities with the TIR domain has led to the use of the term SEFIR for SEF (similar expression to fibroblast growth factors)/IL-17R [95]. Act1, which encodes an apparent SEFIR domain, is essential for IL-17R downstream signalling through mutual SEFIRdependent interactions to activate NF- $\kappa B$ and TAK1 [96]. Act1-deficient cells fail to respond to IL-17, and Act1-deficient mice develop an attenuated form of EAE and colitis [97].

\section{Interleukin-17 and the Th17 lineage}

Until recently, $\mathrm{CD}^{+} \mathrm{T}$ cells were differentiated into two subsets, Th1 and Th2, according to the profile of cytokines produced. Th1 cells produce IFN- $\gamma$ and activated macrophage activities (cell-mediated immunity), leading to the control of intracellular infectious microorganisms. Th2 cells produce IL-4, IL-5, and IL-13, mediate the antibody production (humoral response), and are involved in the defence 
against parasitic infections and in allergic disorders. IL-12, a dimeric cytokine composed of the subunits p40 and p35, plays a critical role in the differentiation of Th1 cells. Although CD4 ${ }^{+}$cells have been known as a source of IL-17 for several years, it is only recently that Th17 cells were recognised as an independent lineage of $\mathrm{T}$ cells responsible for neutrophilic infiltration and immune response against extracellular microorganisms and fungi (reviewed in [98]).

Historically, several of the inflammatory activities of Th17 cells were attributed to Th1 cells because experimental models of autoimmune diseases were inhibited by the use of antibodies against IL-12 p40 or mice deficient in the p40 subunit of IL-12 (reviewed in [99]). However, the use of animals deficient in other critical molecules of the IL-12/IFN- $\gamma$ pathway was associated with an increased severity of different experimental models of autoimmune diseases such as EAE or CIA [100-102]. These apparently opposite observations are now better understood since the discovery of IL-23, a member of the IL-12 family, consisting of the p40 and p19 subunits. Indeed, recent findings on the relative roles of IL-12 and IL-23 in autoimmunity indicated that IL-23, but not IL-12, is critical for the development of some models of autoimmune pathologies $[103,104]$. Most interestingly, a polymorphism in the IL-23R gene has been linked to susceptibility to Crohn disease, ankylosing spondylitis, and psoriasis, thus suggesting a link between the IL-23/Th17 pathway and human diseases $[105,106]$. Successful treatment of Crohn disease and psoriasis with antibodies targeting p40, the common subunit of IL-12 and IL-23, further suggests that IL-23 is involved in the pathogenesis of these diseases $[107,108]$. The effect of ustekinumab, a monoclonal anti-p40 antibody, was examined recently in a randomised double-blind placebocontrolled crossover clinical trial including 146 patients with PsA refractory to non-steroidal anti-inflammatory drugs, classical DMARDs, or TNF- $\alpha$ antagonists. At week 12, the proportion of patients achieving an ACR20 response was significantly higher in ustekinumab-treated patients versus in the placebo group ( $42 \%$ versus $14 \% ; P=0.0002)$. The results were still significant but more modest when using more stringent criteria such as ACR50 and ACR70 with 25\% and $11 \%$ in the ustekinumab versus $7 \%$ and $0 \%$ in the placebo groups achieving these response rates, respectively. The effect on psoriasis seemed stronger than on arthritis as $52 \%$ and $33 \%$ in the ustekinumab and $5 \%$ and $4 \%$ in the placebo groups achieved improvements of $75 \%$ and $90 \%$ in psoriasis area and severity index (PASI), respectively [109]. Further studies should be performed to investigate whether p40 targeting has distinct effects according to the affected organs.

Recent observations indicate that IL-23 is not critical for Th17 commitment from naïve $\mathrm{CD}^{+} \mathrm{T}$ cells but rather is required for the expansion and pathogenicity of Th17 cells. Several studies showed that a complex of cytokines, including transforming growth factor-beta (TGF- $\beta$ ), IL-6, IL-1, and IL-21, drives the differentiation of Th17 cells, although some variations between humans and mice have been described. Murine Th17 differentiation requires the combination of TGF- $\beta$ and IL- $6[110,111]$. The addition of IL- $1 \beta$ and TNF- $\alpha$ can further enhance the Th17 differentiation but cannot replace TGF- $\beta$ or IL-6 [112]. In the absence of IL-6, IL-21 can cooperate with TGF- $\beta$ to induce Th17 cells in IL$6^{-/-} \mathrm{T}$ cells [113]. In humans, IL-1 $\beta$ is the most effective inducer of Th17 cells in naïve $T$ cells in vivo and this differentiation is enhanced when IL- 6 and IL-23 are also present. Thus, IL-1 $\beta$ and IL-23 may be more important in Th17 differentiation in humans than in mice. Another divergence between murine and human systems is the role of TGF- $\beta$. Initial studies have shown that TGF- $\beta$ is not necessary and that it even exerts a suppressor effect on Th17 differentiation [114,115]. A point of debate is that naïve cells obtained from humans are not as truly naïve as those isolated from mice maintained in a germ-free environment. Recently, it has been shown that TGF- $\beta$, in combination with IL-1 $\beta$, IL-6, or IL-21, is required for Th17 differentiation of naïve $T$ cells from umbilical cord blood [116].

The orphan nuclear receptor ROR $\gamma \mathrm{T}$ (retinoic acid-related orphan receptor-gamma-T) (encoded by Rorcyt) has been identified as the key transcription factor regulating the differentiation of Th17 cells [117]. ROR $\gamma \mathrm{T}$ mRNA is induced by IL- 6 and TGF- $\beta$ and is further upregulated by IL- 6 and IL23 activation of STAT3 [118]. The expression of RORC2, human ortholog of mouse ROR $\gamma \mathrm{T}$, in human naïve T cells is also upregulated by stimulation with TGF- $\beta$ and the combinations of TGF- $\beta$ and IL- 6 or TGF- $\beta$ and IL-21 [73]. TGF- $\beta$ stimulates the expression of the forkhead/winged helix transcription factor Foxp3, which is critical for the differentiation of $\mathrm{T}_{\text {reg }}$ cells. It has been observed that ROR $\gamma \mathrm{T}$ and ROR $\alpha$, the transcription factors for Th17, and Foxp3 can physically bind to each other and antagonise each other's function [119]. In line with this observation, the deletion of Foxp3 resulted in an increased ROR $\gamma \mathrm{T}, \mathrm{IL}-17$, and IL-21 expression [120,121]. In addition to CD4 ${ }^{+} \mathrm{T}$ cells, IL-17 is produced by $\mathrm{CD}^{+}$cells, $\gamma \delta \mathrm{T}$ cells, invariant NKT cells, eosinophils, neutrophils, and activated monocytes (reviewed in [122]). Thus, IL-17 is produced by cells belonging to both the innate and adaptative immunity.

\section{Pro-inflammatory effects of interleukin-17}

Several in vitro and in vivo data indicate that $\mathrm{IL}-17$ plays a critical role in acute and chronic inflammatory responses. IL-17 induces the production of IL-1, IL-6, TNF- $\alpha$, inducible NO synthase, matrix metalloproteinases (MMPs), and chemokines by fibroblasts, macrophages, and endothelial cells [123,124]. When cultured in the presence of IL-17, fibroblasts could sustain the proliferation of $\mathrm{CD}^{+} 4^{+}$haematopoietic progenitors and their preferential maturation into neutrophils [125]. IL-17 is especially potent in activating neutrophils through the expansion of their lineage by granulocyte colony-stimulating factor (G-CSF) and G-CSF 
Table 2

\begin{tabular}{|c|c|c|}
\hline & In vitro & In vivo \\
\hline Inflammation & $\begin{array}{l}\text { Neutrophilic response } \\
\text { Stimulation of G-CSF production } \\
\text { Stimulation of CXCL1, Gro } \alpha \text { (mouse) } \\
\text { CXCL8 (human) } \\
\text { T-cell and DC recruitment } \\
\text { CCL20 production } \\
\text { IL-1 and TNF- } \alpha \text { production by macrophages } \\
\text { IL-6, PGE2 production by synovial fibroblasts } \\
\text { NO in articular chondrocytes }\end{array}$ & $\begin{array}{l}\text { IL-17-deficient mice } \\
\text { Attenuated form of CIA } \\
\text { Protected from arthritis in IL-1Ra-deficient mice } \\
\text { No effect in PIA }\end{array}$ \\
\hline Tissue destruction & Production of MMPs & $\begin{array}{l}\text { Intra-articular IL-1 } 7 \text { induces cartilage degradation } \\
\text { Local IL-17 gene transfer induces MMPs and high RANKL/OPG } \\
\text { ratio and osteoclastogenesis } \\
\text { Joint destruction is dependent on IL-17R signalling in } \\
\text { radiation-resistant cells in SCW arthritis }\end{array}$ \\
\hline
\end{tabular}

CIA, collagen-induced arthritis; DC, dendritic cell; G-CSF, granulocyte colony-stimulating factor; IL, interleukin; IL-1 Ra, interleukin-1 receptor antagonist; MMP, matrix metalloproteinase; NO, nitric oxide; OPG, osteoprotegerin; PGE2, prostaglandin E2; PIA, proteoglycan-induced arthritis; RANKL, receptor activator of nuclear factor-kappa-B ligand; SCW, streptococcal cell wall-induced; TNF- $\alpha$, tumour necrosis factor-alpha.

receptor expression as well as their recruitment through the stimulation of chemokines such as CXCL1 and Gro $\alpha$ in mice and IL- 8 in humans. Accordingly, mice deficient in IL-17 are associated with impaired neutrophilic inflammation and are more susceptible to extracellular pathogens such as bacteria and fungi (reviewed in [126]). IL-17 also induces several chemokines responsible for the attraction of autoreactive $\mathrm{T}$ cells and macrophages at the site of inflammation [127].

\section{Interleukin-17 and arthritis}

Pro-inflammatory effects of IL-17 suggest that it participates in the pathogenic mechanisms of RA (Table 2). In synovial fibroblasts, IL-17 stimulated the production of IL-6, IL-8, leukemia inhibitory factor, and prostaglandin E2 [128]. Although IL-1 was more potent in stimulating these responses, IL-17 could act in synergy with IL-1 and TNF- $\alpha$ to induce the production of cytokines and MMPs [128]. IL-17 stimulated the migration of dendritic cells and the recruitment of T cells by inducing the production of MIP $3 \alpha$ (also termed CCL20) [129]. IL-17 contributes also to the development of articular damage by inducing the production of MMP3 and by decreasing the synthesis of proteoglycans by articular chondrocytes [130]. In addition, IL-17 stimulates the osteoclastogenesis by increasing the expression of RANKL (receptor activator of NF- $\mathrm{BB}$ ligand) and the RANKL/osteoprotegerin ratio [131]. Overexpression of IL-17 in the joints of naïve mice resulted in acute inflammation and cartilage proteoglycan depletion that was dependent on TNF- $\alpha$. In contrast, under arthritic conditions, including $\mathrm{K} / \mathrm{BxN}$ serum transfer arthritis and streptococcal cell wall-induced arthritis, the IL-17-induced increased severity of arthritis was independent of TNF- $\alpha$. The incidence and severity of CIA were markedly attenuated in IL-17-deficient mice [132]. With IL-17R-deficient bone marrow chimeric mice, it was reported that the development of severe destructive streptococcal cell wall-induced arthritis was particularly dependent on the presence of intact signalling in radiation-resistant cells [133].

IL-17 also plays a major role downstream to IL-1 signalling and in response to TLR4 ligands. Indeed, IL-1Ra-deficient mice bred into the BALB/c background develop spontaneous polyarthritis due to unopposed IL-1 signalling. However, the occurrence of arthritis is completely suppressed when these mice are crossed with IL-17-deficient mice [124]. Overproduction of IL-23 by antigen-presenting cells represents a possible link between excessive IL-1 stimulation and overproduction of IL-17 in IL-1Ra-deficient mice [134]. Activation of TLR4, which shares common signalling molecules with $\mathrm{IL}-1 \mathrm{R}$, stimulates the production of IL-23 and IL-17 and regulates the severity of experimental arthritis [135].

All together, these experimental findings suggest that the IL-23/IL-17 pathway plays an important role in the pathogenesis of arthritis as well as in various immune-mediated inflammatory diseases that coexist with rheumatologic diseases, including psoriasis and Crohn disease. Recently, a clinical trial examining the efficacy of a monoclonal anti-IL-17 antibody in psoriasis reported very interesting results with major and rapid decrease of skin lesions (unpublished data, presentation by Novartis at the ACR Annual Scientific Meeting 2008). The results of other ongoing clinical trials targeting IL-17 will certainly increase our understanding of the role of this cytokine in human diseases.

\section{Conclusions}

The cytokine field is constantly growing as novel moieties are described. The principal challenges facing us now are to define the most plausible disease-relevant effector pathways 


\section{The Scientific Basis of Rheumatology: years 20 A Decade of Progress}

This article is part of a special collection of reviews, The Scientific Basis of Rheumatology: A Decade of Progress, published to mark Arthritis Research \& Therapy's 10th anniversary.

Other articles in this series can be found at: http://arthritis-research.com/sbr

mediated by novel cytokines and thereafter to determine to what extent they occupy a pivotal role in effector pathogenesis. The success of TNF and IL- 6 blockade in RA and beyond and the encouraging early outcomes with IL-17 and IL-12/23 blockade (p40) in psoriasis suggest that singlecytokine targeting can reap rich rewards in complex polygenic diseases. In the future, rational targeting using pharmacogenomic or protein biomarker-based approaches will enrich high-hurdle response rates. Moreover, rational targeting of combinations of several cytokines, driven by biomarker profiles that define specific functional moieties and patients, may become possible.

\section{Competing interests}

The authors declare that they have no competing interests.

\section{References}

1. Dunn E, Sims JE, Nicklin MJ, O'Neill LA: Annotating genes with potential roles in the immune system: six new members of the IL-1 family. Trends Immuno/ 2001, 22:533-536.

2. Barksby HE, Lea SR, Preshaw PM, Taylor JJ: The expanding family of interleukin-1 cytokines and their role in destructive inflammatory disorders. Clin Exp Immunol 2007, 149:217-225.

3. Barton JL, Herbst R, Bosisio D, Higgins L, Nicklin MJ: A tissue specific IL-1 receptor antagonist homolog from the IL-1 cluster lacks IL-1, IL-1 ra, IL-18 and IL-18 antagonist activities. Eur J Immuno/ 2000, 30:3299-3308.

4. Busfield SJ, Comrack CA, Yu G, Chickering TW, Smutko JS, Zhou H, Leiby KR, Holmgren LM, Gearing DP, Pan Y: Identification and gene organization of three novel members of the IL-1 family on human chromosome 2. Genomics 2000, 66:213-216.

5. Debets R, Timans JC, Homey B, Zurawski S, Sana TR, Lo S, Wagner J, Edwards G, Clifford T, Menon S, Bazan JF, Kastelein RA: Two novel IL-1 family members, IL-1 delta and IL-1 epsilon, function as an antagonist and agonist of NF-kappa B activation through the orphan IL-1 receptor-related protein 2. $J$ Immunol 2001, 167:1440-1446.

6. Kumar S, McDonnell PC, Lehr R, Tierney L, Tzimas MN, Griswold DE, Capper EA, Tal-Singer R, Wells Gl, Doyle ML, Young PR: Identification and initial characterization of four novel members of the interleukin-1 family. J Biol Chem 2000, 275: 10308-10314.

7. Mulero JJ, Pace AM, Nelken ST, Loeb DB, Correa TR, Drmanac R, Ford JE: IL1HY1: a novel interleukin-1 receptor antagonist gene. Biochem Biophys Res Commun 1999, 263:702-706.

8. Pan G, Risser P, Mao W, Baldwin DT, Zhong AW, Filvaroff E, Yansura D, Lewis L, Eigenbrot C, Henzel WJ, Vandlen R: IL-1H, an interleukin 1-related protein that binds IL-18 receptor/IL1Rrp. Cytokine 2001, 13:1-7.
9. Towne JE, Garka KE, Renshaw BR, Virca GD, Sims JE: Interleukin (IL)-1F6, IL-1F8, and IL-1F9 signal through IL-1Rrp2 and IL-1RAcP to activate the pathway leading to NF-kappaB and MAPKs. J Biol Chem 2004, 279:13677-13688.

10. Magne D, Palmer G, Barton JL, Mézin F, Talabot-Ayer D, Bas S, Duffy T, Noger M, Guerne PA, Nicklin MJ, Gabay C: The new IL-1 family member IL-1F8 stimulates production of inflammatory mediators by synovial fibroblasts and articular chondrocytes. Arthritis Res Ther 2006, 8:R80.

11. Blumberg H, Dinh H, Trueblood ES, Pretorius J, Kugler D, Weng N, Kanaly ST, Towne JE, Willis CR, Kuechle MK, Sims JE, Peschon JJ: Opposing activities of two novel members of the IL-1 ligand family regulate skin inflammation. J Exp Med 2007, 204:2603-2614.

12. Schmitz J, Owyang A, Oldham E, Song Y, Murphy E, McClanahan TK, Zurawski G, Moshrefi M, Qin J, Li X, Gorman DM, Bazan JF, Kastelein RA: IL-33, an interleukin-1-like cytokine that signals via the IL-1 receptor-related protein ST2 and induces T helper type 2-associated cytokines. Immunity 2005, 23:479-490.

13. Brint EK, Fitzgerald KA, Smith P, Coyle AJ, Gutierrez-Ramos JC, Fallon PG, O'Neill LA: Characterization of signaling pathways activated by the interleukin 1 (IL-1) receptor homologue T1/ST2. A role for Jun $\mathrm{N}$-terminal kinase in IL-4 induction. $J$ Biol Chem 2002, 277:49205-49211.

14. Baekkevold ES, Roussigne $M$, Yamanaka $T$, Johansen FE, Jahnsen FL, Amalric F, Brandtzaeg P, Erard M, Haraldsen G, Girard JP: Molecular characterization of NF-HEV, a nuclear factor preferentially expressed in human high endothelial venules. $\mathrm{Am} J$ Pathol 2003, 163:69-79.

15. Werman A, Werman-Venkert R, White R, Lee JK, Werman B, Krelin $\mathrm{Y}$, Voronov E, Dinarello CA, Apte RN: The precursor form of IL-1alpha is an intracrine proinflammatory activator of transcription. Proc Natl Acad Sci U S A 2004, 101:2434-2439.

16. Carriere V, Roussel L, Ortega N, Lacorre DA, Americh L, Aguilar L, Bouche G, Girard JP: IL-33, the IL-1-like cytokine ligand for ST2 receptor, is a chromatin-associated nuclear factor in vivo. Proc Natl Acad Sci U S A 2007, 104:282-287.

17. Hayakawa $H$, Hayakawa M, Kume A, Tominaga S: Soluble ST2 blocks interleukin-33 signaling in allergic airway inflammation. J Biol Chem 2007, 282:26369-26380.

18. Trajkovic V, Sweet MJ, Xu D: T1/ST2-an IL-1 receptor-like modulator of immune responses. Cytokine Growth Factor Rev 2004, 15:87-95.

19. Brunner M, Krenn C, Roth G, Moser B, Dworschak M, JensenJarolim E, Spittler A, Sautner T, Bonaros N, Wolner E, Boltz-Nitulescu G, Ankersmit HJ: Increased levels of soluble ST2 protein and IgG1 production in patients with sepsis and trauma. Intensive Care Med 2004, 30:1468-1473.

20. Brint EK, Xu D, Liu H, Dunne A, McKenzie AN, O'Neill LA, Liew FY: ST2 is an inhibitor of interleukin 1 receptor and Toll-like receptor 4 signaling and maintains endotoxin tolerance. Nat Immunol 2004, 5:373-379.

21. Sweet MJ, Leung BP, Kang D, Sogaard M, Schulz K, Trajkovic V, Campbell CC, Xu D, Liew FY: A novel pathway regulating lipopolysaccharide-induced shock by ST2/T1 via inhibition of Tolllike receptor 4 expression. J Immuno/ 2001, 166:6633-6639.

22. Yin $\mathrm{H}$, Huang BJ, Yang H, Huang YF, Xiong $\mathrm{P}$, Zheng F, Chen XP, Chen YF, Gong FL: Pretreatment with soluble ST2 reduces warm hepatic ischemia/reperfusion injury. Biochem Biophys Res Commun 2006, 351:940-946.

23. Fagundes CT, Amaral FA, Souza AL, Vieira AT, Xu D, Liew FY, Souza DG, Teixeira MM: ST2, an IL-1R family member, attenuates inflammation and lethality after intestinal ischemia and reperfusion. J Leukoc Biol 2007, 81:492-499.

24. Miller AM, Xu D, Asquith DL, Denby L, Li Y, Sattar N, Baker AH, Mclnnes IB, Liew FY: IL-33 reduces the development of atherosclerosis. J Exp Med 2008, 205:339-346.

25. Lee DM, Friend DS, Gurish MF, Benoist C, Mathis D, Brenner MB: Mast cells: a cellular link between autoantibodies and inflammatory arthritis. Science 2002, 297:1689-1692.

26. Nigrovic PA, Binstadt BA, Monach PA, Johnsen A, Gurish M, Iwakura $Y$, Benoist $C$, Mathis D, Lee DM: Mast cells contribute to initiation of autoantibody-mediated arthritis via IL-1. Proc Natl Acad Sci U S A 2007, 104:2325-2330.

27. Leung $B P, X u D$, Culshaw $S$, Mclnnes IB, Liew FY: A novel therapy of murine collagen-induced arthritis with soluble T1/ST2. J Immuno/ 2004, 173:145-150. 
28. Xu D, Jiang HR, Kewin P, Li Y, Mu R, Fraser AR, Pitman N, Kurowska-Stolarska M, McKenzie AN, Mclnnes IB, Liew FY: IL-33 exacerbates antigen-induced arthritis by activating mast cells. Proc Natl Acad Sci U S A 2008, 105:10913-10918.

29. Palmer G, Talabot-Ayer D, Lamacchia C, Toy D, Seemayer CA, Viatte S, Finckh A, Smith DE, Gabay C: Inhibition of interleukin33 signaling attenuates the severity of experimental arthritis. Arthritis Rheum 2009, 60:738-749.

30. Smith DE, Renshaw BR, Ketchem RR, Kubin M, Garka KE, Sims JE: Four new members expand the interleukin-1 superfamily. $J$ Biol Chem 2000, 275:1169-1175.

31. Bufler P, Azam T, Gamboni-Robertson F, Reznikov LL, Kumar S, Dinarello CA, Kim SH: A complex of the IL-1 homologue IL1F7b and IL-18-binding protein reduces IL-18 activity. Proc Natl Acad Sci U S A 2002, 99:13723-13728.

32. Lin H, Ho AS, Haley-Vicente D, Zhang J, Bernal-Fussell J, Pace AM, Hansen D, Schweighofer K, Mize NK, Ford JE: Cloning and characterization of IL-1HY2, a novel interleukin-1 family member. J Biol Chem 2001, 276:20597-20602.

33. Arend WP, Palmer G, Gabay C: IL-1, IL-18, and IL-33 families of cytokines. Immunol Rev 2008, 223:20-38.

34. Gracie JA, Forsey RJ, Chan WL, Gilmour A, Leung BP, Greer MR, Kennedy K, Carter R, Wei XQ, Xu D, Field M, Foulis A, Liew FY, Mclnnes IB: A proinflammatory role for IL-18 in rheumatoid arthritis. J Clin Invest 1999, 104:1393-1401.

35. Matsui K, Yoshimoto T, Tsutsui H, Hyodo Y, Hayashi N, Hiroishi K, Kawada N, Okamura H, Nakanishi K, Higashino K: Propionibacterium acnes treatment diminishes $\mathrm{CD}^{+}{ }^{+} \mathrm{NK1.1}{ }^{+} \mathrm{T}$ cells but induces type I T cells in the liver by induction of IL-12 and IL18 production from Kupffer cells. J Immunol 1997, 159:97-106.

36. Pizarro TT, Michie MH, Bentz M, Woraratanadharm J, Smith MF Jr., Foley E, Moskaluk CA, Bickston SJ, Cominelli F: IL-18, a novel immunoregulatory cytokine, is up-regulated in Crohn's disease: expression and localization in intestinal mucosal cells. J Immunol 1999, 162:6829-6835.

37. Prinz M, Hanisch UK: Murine microglial cells produce and respond to interleukin-18. J Neurochem 1999, 72:2215-2218.

38. Stoll S, Jonuleit H, Schmitt E, Muller G, Yamauchi H, Kurimoto M, Knop J, Enk AH: Production of functional IL-18 by different subtypes of murine and human dendritic cells (DC): DCderived IL-18 enhances IL-12-dependent Th1 development. Eur J Immunol 1998, 28:3231-3239.

39. Gu Y, Kuida K, Tsutsui H, Ku G, Hsiao K, Fleming MA, Hayashi N, Higashino K, Okamura H, Nakanishi K, Kurimoto M, Tanimoto T, Flavell RA, Sato V, Harding MW, Livingston DJ, Su MS: Activation of interferon-gamma inducing factor mediated by interleukin-1beta converting enzyme. Science 1997, 275:206-209.

40. Ghayur T, Banerjee S, Hugunin M, Butler D, Herzog L, Carter A, Quintal L, Sekut L, Talanian R, Paskind M, Wong W, Kamen R, Tracey D, Allen H: Caspase-1 processes IFN-gamma-inducing factor and regulates LPS-induced IFN-gamma production. Nature 1997, 386:619-623.

41. Ferrari D, Pizzirani C, Adinolfi E, Lemoli RM, Curti A, Idzko M, Panther E, Di Virgilio F: The P2X7 receptor: a key player in IL-1 processing and release. J Immuno/ 2006, 176:3877-3883.

42. Cheung H, Chen NJ, Cao Z, Ono N, Ohashi PS, Yeh WC: Accessory protein-like is essential for IL-18-mediated signaling. $J$ Immunol 2005, 174:5351-5357.

43. van Kuijk AW, Reinders-Blankert $P$, Smeets TJ, Dijkmans BA, Tak PP: Detailed analysis of the cell infiltrate and the expression of mediators of synovial inflammation and joint destruction in the synovium of patients with psoriatic arthritis: implications for treatment. Ann Rheum Dis 2006, 65:1551-1557.

44. Rooney T, Murphy E, Benito M, Roux-Lombard P, FitzGerald O, Dayer JM, Bresnihan B: Synovial tissue interleukin-18 expression and the response to treatment in patients with inflammatory arthritis. Ann Rheum Dis 2004, 63:1393-1398.

45. Yamada N, Niwa S, Tsujimura T, Iwasaki T, Sugihara A, Futani $H$, Hayashi S, Okamura $\mathrm{H}$, Akedo $\mathrm{H}$, Terada $\mathrm{N}$ : Interleukin-18 and interleukin-12 synergistically inhibit osteoclastic bone-resorbing activity. Bone 2002, 30:901-908.

46. Tak PP, Bacchi M, Bertolino $M$ : Pharmacokinetics of IL-18 binding protein in healthy volunteers and subjects with rheumatoid arthritis or plaque psoriasis. Eur J Drug Metab Pharmacokinet 2006, 31:109-116.

47. Kim SH, Han SY, Azam T, Yoon DY, Dinarello CA: Interleukin-32: a cytokine and inducer of TNFalpha. Immunity 2005, 22:131-142.
48. Dinarello CA, Kim SH: IL-32, a novel cytokine with a possible role in disease. Ann Rheum Dis 2006, 65 Suppl 3:iii61-64.

49. Netea MG, Azam T, Lewis EC, Joosten LA, Wang M, Langenberg D, Meng X, Chan ED, Yoon DY, Ottenhoff T, Kim SH, Dinarello CA: Mycobacterium tuberculosis induces interleukin-32 production through a caspase-1/IL-18/interferon-gamma-dependent mechanism. PLoS Med 2006, 3:e277.

50. Mclnnes IB, al-Mughales J, Field M, Leung BP, Huang FP, Dixon $\mathrm{R}$, Sturrock RD, Wilkinson PC, Liew FY: The role of interleukin15 in T-cell migration and activation in rheumatoid arthritis. Nat Med 1996, 2:175-182.

51. Harada S, Yamamura M, Okamoto $H$, Morita $Y$, Kawashima M, Aita T, Makino H: Production of interleukin-7 and interleukin15 by fibroblast-like synoviocytes from patients with rheumatoid arthritis. Arthritis Rheum 1999, 42:1508-1516.

52. Grabstein KH, Eisenman J, Shanebeck K, Rauch C, Srinivasan S, Fung V, Beers C, Richardson J, Schoenborn MA, Ahdieh M, Johnson L, Alderson MR, Watson JD, Anderson DM, Giri JG: Cloning of a $\mathrm{T}$ cell growth factor that interacts with the beta chain of the interleukin-2 receptor. Science 1994, 264:965968.

53. Waldmann TA, Tagaya $Y$ : The multifaceted regulation of interleukin-15 expression and the role of this cytokine in NK cell differentiation and host response to intracellular pathogens. Annu Rev Immunol 1999, 17:19-49.

54. Onu A, Pohl T, Krause H, Bulfone-Paus S: Regulation of IL-15 secretion via the leader peptide of two IL-15 isoforms. J Immunol 1997, 158:255-262.

55. Tagaya Y, Kurys G, Thies TA, Losi JM, Azimi N, Hanover JA, Bamford RN, Waldmann TA: Generation of secretable and nonsecretable interleukin 15 isoforms through alternate usage of signal peptides. Proc Natl Acad Sci US A 1997, 94:1444414449.

56. Bulanova E, Budagian V, Orinska Z, Krause H, Paus R, BulfonePaus S: Mast cells express novel functional IL-15 receptor alpha isoforms. J Immunol 2003, 170:5045-5055.

57. Dubois S, Mariner J, Waldmann TA, Tagaya Y: IL-15Ralpha recycles and presents IL-15 In trans to neighboring cells. Immunity 2002, 17:537-547.

58. Tagaya Y, Bamford RN, DeFilippis AP, Waldmann TA: IL-15: a pleiotropic cytokine with diverse receptor/signaling pathways whose expression is controlled at multiple levels. Immunity 1996, 4:329-336.

59. Tagaya Y, Burton JD, Miyamoto Y, Waldmann TA: Identification of a novel receptor/signal transduction pathway for IL- 15/T in mast cells. EMBO J 1996, 15:4928-4939.

60. Mclnnes IB, Gracie JA: Interleukin-15: a new cytokine target for the treatment of inflammatory diseases. Curr Opin Pharmacol 2004, 4:392-397.

61. Lodolce J, Burkett $\mathrm{P}$, Koka $\mathrm{R}$, Boone $\mathrm{D}$, Chien $\mathrm{M}$, Chan F, Madonia M, Chai S, Ma A: Interleukin-15 and the regulation of lymphoid homeostasis. Mol Immunol 2002, 39:537-544.

62. Kane D, Gogarty M, O'Leary J, Silva I, Bermingham N, Bresnihan $B$, Fitzgerald $O$ : Reduction of synovial sublining layer inflammation and proinflammatory cytokine expression in psoriatic arthritis treated with methotrexate. Arthritis Rheum 2004, 50: 3286-3295.

63. Smolewska E, Brozik H, Smolewski $P$, Biernacka-Zielinska M Darzynkiewicz Z, Stanczyk J: Apoptosis of peripheral blood lymphocytes in patients with juvenile idiopathic arthritis. Ann Rheum Dis 2003, 62:761-763.

64. Chan A, Filer A, Parsonage G, Kollnberger S, Gundle R, Buckley $C D$, Bowness $P$ : Mediation of the proinflammatory cytokine response in rheumatoid arthritis and spondylarthritis by interactions between fibroblast-like synoviocytes and natural killer cells. Arthritis Rheum 2008, 58:707-717.

65. Kurowska M, Rudnicka W, Kontny E, Janicka I, Chorazy M, Kowalczewski J, Ziolkowska M, Ferrari-Lacraz S, Strom TB, Maslinski W: Fibroblast-like synoviocytes from rheumatoid arthritis patients express functional IL-15 receptor complex: endogenous IL-15 in autocrine fashion enhances cell proliferation and expression of $\mathrm{Bcl}-\mathrm{x}(\mathrm{L})$ and $\mathrm{Bcl}-2$. J Immunol 2002, 169: 1760-1767.

66. Wakisaka S, Suzuki N, Nagafuchi H, Takeba Y, Kaneko A, Asai T, Sakane T: Characterization of tissue outgrowth developed in vitro in patients with rheumatoid arthritis: involvement of $\mathrm{T}$ cells in the development of tissue outgrowth. Int Arch Allergy 
Immunol 2000, 121:68-79.

67. Ling SM, Patel DD, Garnero $P$, Zhan $M$, Vaduganathan $M$, Muller D, Taub D, Bathon JM, Hochberg M, Abernethy DR, Metter EJ, Ferrucci L: Serum protein signatures detect early radiographic osteoarthritis. Osteoarthritis Cartilage 2009, 17:43-48.

68. Ziolkowska M, Koc A, Luszczykiewicz G, Ksiezopolska-Pietrzak K, Klimczak E, Chwalinska-Sadowska H, Maslinski W: High levels of IL-17 in rheumatoid arthritis patients: IL-15 triggers in vitro IL17 production via cyclosporin A-sensitive mechanism. J Immunol 2000, 164:2832-2838.

69. Sen M, Lauterbach K, El-Gabalawy H, Firestein GS, Corr M, Carson DA: Expression and function of wingless and frizzled homologs in rheumatoid arthritis. Proc Natl Acad Sci USA 2000, 97:2791-2796.

70. Spolski R, Leonard WJ: The Yin and Yang of interleukin-21 in allergy, autoimmunity and cancer. Curr Opin Immunol 2008, 20:295-301.

71. Ettinger R, Kuchen S, Lipsky PE: The role of IL-21 in regulating B-cell function in health and disease. Immunol Rev 2008, 223: 60-86.

72. Vogelzang A, McGuire HM, Yu D, Sprent J, Mackay CR, King C: A fundamental role for interleukin-21 in the generation of $T$ follicular helper cells. Immunity 2008, 29:127-137.

73. Yang L, Anderson DE, Baecher-Allan C, Hastings WD, Bettelli E, Oukka M, Kuchroo VK, Hafler DA: IL-21 and TGF-beta are required for differentiation of human $\mathrm{T}(\mathrm{H}) 17$ cells. Nature 2008, 454:350-352.

74. Huber M, Brustle A, Reinhard K, Guralnik A, Walter G, Mahiny A, von Low E, Lohoff M: IRF4 is essential for IL-21-mediated induction, amplification, and stabilization of the Th17 phenotype. Proc Natl Acad Sci U S A 2008, 105:20846-20851.

75. Bauquet AT, Jin H, Paterson AM, Mitsdoerffer M, Ho IC, Sharpe $\mathrm{AH}$, Kuchroo VK: The costimulatory molecule ICOS regulates the expression of c-Maf and IL-21 in the development of follicular T helper cells and TH-17 cells. Nat Immunol 2009, 10: 167-175.

76. Thedrez A, Harly C, Morice A, Salot S, Bonneville M, Scotet E: IL21-mediated potentiation of antitumor cytolytic and proinflammatory responses of human Vgamma9Vdelta2 T cells for adoptive immunotherapy. J Immunol 2009, 182:3423-3431.

77. Liu Z, Yang L, Cui Y, Wang X, Guo C, Huang Z, Kan Q, Liu Y: II21 enhances NK cell activation and cytolytic activity and induces Th17 cell differentiation in inflammatory bowel disease. Inflamm Bowel Dis 2009, Mar 25. [Epub ahead of print].

78. Pesu M, Laurence A, Kishore N, Zwillich SH, Chan G, O'Shea JJ: Therapeutic targeting of Janus kinases. Immunol Rev 2008, 223:132-142

79. Williams W, Scherle P, Shi J, Newton R, McKeever E, Fridman J, Burn T, Vaddi K, Levy R, Moreland L: A randomized placebocontrolled study of INCB018424, a selective janus kinase 1 \& 2 (JAK1 \& 2) inhibitor in rheumatoid arthritis (RA). Arthritis Rheum 2008, 58:S431-S431.

80. Langrish CL, McKenzie BS, Wilson NJ, de Waal Malefyt $R$, Kastelein RA, Cua DJ: IL-12 and IL-23: master regulators of innate and adaptive immunity. Immunol Rev 2004, 202:96-105.

81. Kastelein RA, Hunter CA, Cua DJ: Discovery and biology of IL23 and IL-27: related but functionally distinct regulators of inflammation. Annu Rev Immunol 2007, 25:221-242.

82. Villarino AV, Stumhofer JS, Saris CJ, Kastelein RA, de Sauvage FJ, Hunter CA: IL-27 limits IL-2 production during Th1 differentiation. J Immunol 2006, 176:237-247.

83. Villarino A, Hibbert L, Lieberman L, Wilson E, Mak T, Yoshida H, Kastelein RA, Saris C, Hunter CA: The IL-27R (WSX-1) is required to suppress $T$ cell hyperactivity during infection. Immunity 2003, 19:645-655.

84. Fitzgerald DC, Ciric B, Touil T, Harle H, Grammatikopolou J, Das Sarma J, Gran B, Zhang GX, Rostami A: Suppressive effect of IL-27 on encephalitogenic Th17 cells and the effector phase of experimental autoimmune encephalomyelitis. J Immunol 2007, 179:3268-3275.

85. Batten M, Li J, Yi S, Kljavin NM, Danilenko DM, Lucas S, Lee J, de Sauvage FJ, Ghilardi N: Interleukin 27 limits autoimmune encephalomyelitis by suppressing the development of interleukin 17-producing T cells. Nat Immuno/ 2006, 7:929-936.

86. Niedbala W, Cai B, Wei X, Patakas A, Leung BP, Mclnnes IB, Liew FY: Interleukin 27 attenuates collagen-induced arthritis. Ann Rheum Dis 2008, 67:1474-1479.
87. Collison LW, Workman CJ, Kuo TT, Boyd K, Wang Y, Vignali KM, Cross R, Sehy D, Blumberg RS, Vignali DA: The inhibitory cytokine IL-35 contributes to regulatory T-cell function. Nature 2007, 450:566-569.

88. Niedbala W, Wei XQ, Cai B, Hueber AJ, Leung BP, Mclnnes IB, Liew FY: IL-35 is a novel cytokine with therapeutic effects against collagen-induced arthritis through the expansion of regulatory $T$ cells and suppression of Th17 cells. Eur J Immunol 2007, 37:3021-3029.

89. Yao Z, Painter SL, Fanslow WC, Ulrich D, Macduff BM, Spriggs MK, Armitage RJ: Human IL-17: a novel cytokine derived from T cells. J Immunol 1995, 155:5483-5486.

90. Moseley TA, Haudenschild DR, Rose L, Reddi AH: Interleukin-17 family and IL-17 receptors. Cytokine Growth Factor Rev 2003 14:155-174.

91. Wright JF, Guo Y, Quazi A, Luxenberg DP, Bennett F, Ross JF, Qiu Y, Whitters MJ, Tomkinson KN, Dunussi-Joannopoulos K, Carreno BM, Collins M, Wolfman NM: Identification of an interleukin 17F/17A heterodimer in activated human $\mathrm{CD} 4{ }^{+} \mathrm{T}$ cells. J Biol Chem 2007, 282:13447-13455.

92. Kuestner RE, Taft DW, Haran A, Brandt CS, Brender T, Lum K, Harder B, Okada S, Ostrander CD, Kreindler JL, Aujla SJ, Reardon B, Moore M, Shea P, Schreckhise R, Bukowski TR, Presnell S, Guerra-Lewis P, Parrish-Novak J, Ellsworth JL, Jaspers S, Lewis KE, Appleby M, Kolls JK, Rixon M, West JW, Gao Z, Levin SD: Identification of the IL-17 receptor related molecule IL$17 R C$ as the receptor for IL-17F. J Immunol 2007, 179:5462. 5473

93. Wright JF, Bennett F, Li B, Brooks J, Luxenberg DP, Whitters MJ, Tomkinson KN, Fitz LJ, Wolfman NM, Collins M, DunussiJoannopoulos K, Chatterjee-Kishore M, Carreno BM: The human IL-17F/IL-17A heterodimeric cytokine signals through the IL-17RA/IL-17RC receptor complex. J Immunol 2008, 181: 2799-2805.

94. Haudenschild D, Moseley T, Rose L, Reddi AH: Soluble and transmembrane isoforms of novel interleukin-17 receptor-like protein by RNA splicing and expression in prostate cancer. $J$ Biol Chem 2002, 277:4309-4316.

95. Novatchkova M, Leibbrandt A, Werzowa J, Neubuser A, Eisenhaber F: The STIR-domain superfamily in signal transduction, development and immunity. Trends Biochem Sci 2003, 28: 226-229.

96. Qian Y, Liu C, Hartupee J, Altuntas CZ, Gulen MF, Jane-Wit D, Xiao J, Lu Y, Giltiay N, Liu J, Kordula T, Zhang OW, Vallance B, Swaidani S, Aronica M, Tuohy VK, Hamilton T, Li X: The adaptor Act1 is required for interleukin 17-dependent signaling associated with autoimmune and inflammatory disease. Nat Immunol 2007, 8:247-256.

97. Li X: Act1 modulates autoimmunity through its dual functions in CD40L/BAFF and IL-17 signaling. Cytokine 2008, 41:105113.

98. Romagnani S: Human Th17 cells. Arthritis Res Ther 2008, 10: 206.

99. Gately MK, Renzetti LM, Magram J, Stern AS, Adorini L, Gubler U, Presky DH: The interleukin-12/interleukin-12-receptor system: role in normal and pathologic immune responses. Annu Rev Immunol 1998, 16:495-521.

100. Bettelli E, Sullivan B, Szabo SJ, Sobel RA, Glimcher LH, Kuchroo VK: Loss of T-bet, but not STAT1, prevents the development of experimental autoimmune encephalomyelitis. J Exp Med 2004, 200:79-87.

101. Hunter CA: New IL-12-family members: IL-23 and IL-27, cytokines with divergent functions. Nat Rev Immunol 2005, 5: 521-531.

102. McKenzie BS, Kastelein RA, Cua DJ: Understanding the IL-23IL-17 immune pathway. Trends Immuno/ 2006, 27:17-23.

103. Cua DJ, Sherlock J, Chen Y, Murphy CA, Joyce B, Seymour B, Lucian L, To W, Kwan S, Churakova T, Zurawski S, Wiekowski M, Lira SA, Gorman D, Kastelein RA, Sedgwick JD: Interleukin-23 rather than interleukin-12 is the critical cytokine for autoimmune inflammation of the brain. Nature 2003, 421:744-748.

104. Murphy CA, Langrish CL, Chen Y, Blumenschein W, McClanahan T, Kastelein RA, Sedgwick JD, Cua DJ: Divergent pro- and antiinflammatory roles for IL-23 and IL-12 in joint autoimmune inflammation. J Exp Med 2003, 198:1951-1957.

105. Duerr RH, Taylor KD, Brant SR, Rioux JD, Silverberg MS, Daly MJ, Steinhart AH, Abraham C, Regueiro M, Griffiths A, Dassopoulos 
T, Bitton A, Yang H, Targan S, Datta LW, Kistner EO, Schumm LP, Lee AT, Gregersen PK, Barmada MM, Rotter JI, Nicolae DL, Cho JH: A genome-wide association study identifies IL23R as an inflammatory bowel disease gene. Science 2006, 314: 1461-1463.

106. Cargill M, Schrodi SJ, Chang M, Garcia VE, Brandon R, Callis KP, Matsunami N, Ardlie KG, Civello D, Catanese JJ, Leong DU, Panko JM, McAllister LB, Hansen CB, Papenfuss J, Prescott SM, White TJ, Leppert MF, Krueger GG, Begovich AB: A large-scale genetic association study confirms IL12B and leads to the identification of IL23R as psoriasis-risk genes. Am J Hum Genet 2007, 80:273-290.

107. Mannon PJ, Fuss IJ, Mayer L, Elson CO, Sandborn WJ, Present D, Dolin B, Goodman N, Groden C, Hornung RL, Quezado M, Yang Z, Neurath MF, Salfeld J, Veldman GM, Schwertschlag U, Strober W; Anti-IL-12 Crohn's Disease Study Group: Anti-interleukin-12 antibody for active Crohn's disease. N Engl J Med 2004, 351: 2069-2079.

108. Krueger GG, Langley RG, Leonardi C, Yeilding N, Guzzo C, Wang Y, Dooley LT, Lebwohl M: A human interleukin-12/23 monoclonal antibody for the treatment of psoriasis. $N$ Engl J Med 2007, 356:580-592.

109. Gottlieb A, Menter A, Mendelsohn A, Shen YK, Li S, Guzzo C, Fretzin $S$, Kunynetz R, Kavanaugh A: Ustekinumab, a human interleukin 12/23 monoclonal antibody, for psoriatic arthritis: randomised, double-blind, placebo-controlled, crossover trial. Lancet 2009, 373:633-640.

110. Bettelli E, Carrier Y, Gao W, Korn T, Strom TB, Oukka M, Weiner $\mathrm{HL}$, Kuchroo VK: Reciprocal developmental pathways for the generation of pathogenic effector TH17 and regulatory T cells. Nature 2006, 441:235-238.

111. Mangan PR, Harrington LE, O'Quinn DB, Helms WS, Bullard DC, Elson CO, Hatton RD, Wahl SM, Schoeb TR, Weaver CT: Transforming growth factor-beta induces development of the $\mathrm{T}(\mathrm{H}) 17$ lineage. Nature 2006, 441:231-234.

112. Veldhoen M, Hocking RJ, Atkins CJ, Locksley RM, Stockinger B: TGFbeta in the context of an inflammatory cytokine milieu supports de novo differentiation of IL-17-producing $\mathrm{T}$ cells. Immunity 2006, 24:179-189.

113. Korn T, Bettelli E, Gao W, Awasthi A, Jager A, Strom TB, Oukka M, Kuchroo VK: IL-21 initiates an alternative pathway to induce proinflammatory $\mathrm{T}(\mathrm{H}) 17$ cells. Nature 2007, 448:484-487.

114. Acosta-Rodriguez EV, Napolitani G, Lanzavecchia A, Sallusto F: Interleukins 1 beta and 6 but not transforming growth factorbeta are essential for the differentiation of interleukin 17-producing human T helper cells. Nat Immunol 2007, 8:942-949.

115. Wilson NJ, Boniface K, Chan JR, McKenzie BS, Blumenschein WM, Mattson JD, Basham B, Smith K, Chen T, Morel F, Lecron JC, Kastelein RA, Cua DJ, McClanahan TK, Bowman EP, de Waal Malefyt R: Development, cytokine profile and function of human interleukin 17-producing helper T cells. Nat Immunol 2007, 8:950-957.

116. Manel N, Unutmaz D, Littman DR: The differentiation of human $T(H)-17$ cells requires transforming growth factor-beta and induction of the nuclear receptor RORgammat. Nat Immunol 2008, 9:641-649.

117. Ivanov II, McKenzie BS, Zhou L, Tadokoro CE, Lepelley A, Lafaille JJ, Cua DJ, Littman DR: The orphan nuclear receptor RORgammat directs the differentiation program of proinflammatory IL$17^{+}$T helper cells. Cell 2006, 126:1121-1133.

118. Yang $X O$, Panopoulos AD, Nurieva $R$, Chang $S H$, Wang $D$, Watowich SS, Dong C: STAT3 regulates cytokine-mediated generation of inflammatory helper T cells. J Biol Chem 2007, 282:9358-9363.

119. Zhou L, Lopes JE, Chong MM, Ivanov II, Min R, Victora GD, Shen Y, Du J, Rubtsov YP, Rudensky AY, Ziegler SF, Littman DR: TGFbeta-induced Foxp3 inhibits $\mathrm{T}(\mathrm{H}) 17$ cell differentiation by antagonizing RORgammat function. Nature 2008, 453:236240.

120. Gavin MA, Rasmussen JP, Fontenot JD, Vasta V, Manganiello VC, Beavo JA, Rudensky AY: Foxp3-dependent programme of regulatory T-cell differentiation. Nature 2007, 445:771-775.

121. Williams LM, Rudensky AY: Maintenance of the Foxp3-dependent developmental program in mature regulatory $T$ cells requires continued expression of Foxp3. Nat Immunol 2007, 8: 277-284.

122. Bettelli E, Korn T, Oukka M, Kuchroo VK: Induction and effector functions of $\mathrm{T}(\mathrm{H}) 17$ cells. Nature 2008, 453:1051-1057.

123. Kolls JK, Linden A: Interleukin-17 family members and inflammation. Immunity 2004 21:467-476.

124. Nakae S, Saijo S, Horai R, Sudo K, Mori S, Iwakura Y: IL-17 production from activated $T$ cells is required for the spontaneous development of destructive arthritis in mice deficient in IL-1 receptor antagonist. Proc Natl Acad Sci U S A 2003, 100: 5986-5990.

125. Fossiez F, Djossou O, Chomarat P, Flores-Romo L, Ait-Yahia S, Maat C, Pin JJ, Garrone P, Garcia E, Saeland S, Blanchard D, Gaillard C, Das Mahapatra B, Rouvier E, Golstein P, Banchereau J, Lebecque S: T cell interleukin-17 induces stromal cells to produce proinflammatory and hematopoietic cytokines. J Exp Med 1996, 183:2593-2603.

126. Gaffen SL: An overview of IL-17 function and signaling. Cytokine 2008, 43:402-407.

127. Park $H, L i Z$, Yang $X O$, Chang $S H$, Nurieva $R$, Wang $Y H$, Wang $Y$, Hood L, Zhu Z, Tian Q, Dong C: A distinct lineage of CD4 T cells regulates tissue inflammation by producing interleukin 17. Nat Immunol 2005, 6:1133-1141.

128. Miossec P: Interleukin-17 in rheumatoid arthritis: if $\mathrm{T}$ cells were to contribute to inflammation and destruction through synergy. Arthritis Rheum 2003, 48:594-601.

129. Chabaud M, Page G, Miossec P: Enhancing effect of IL-1, IL-17, and TNF-alpha on macrophage inflammatory protein-3alpha production in rheumatoid arthritis: regulation by soluble receptors and Th2 cytokines. J Immuno/ 2001, 167:6015-6020.

130. Lubberts E, Joosten LA, van de Loo FA, van den Gersselaar LA van den Berg WB: Reduction of interleukin-17-induced inhibition of chondrocyte proteoglycan synthesis in intact murine articular cartilage by interleukin-4. Arthritis Rheum 2000, 43: 1300-1306.

131. Lubberts $E$, van den Bersselaar L, Oppers-Walgreen B, Schwarzenberger $\mathrm{P}$, Coenen-de Roo CJ, Kolls JK, Joosten LA, van den Berg WB: IL-17 promotes bone erosion in murine collagen-induced arthritis through loss of the receptor activator of NF-kappa B ligand/osteoprotegerin balance. J Immuno/ 2003 170:2655-2662.

132. Nakae S, Nambu A, Sudo K, Iwakura Y: Suppression of immune induction of collagen-induced arthritis in IL-17-deficient mice. $J$ Immunol 2003, 171:6173-6177.

133. Lubberts E, Schwarzenberger $P$, Huang W, Schurr JR, Peschon $\mathrm{JJ}$, van den Berg WB, Kolls JK: Requirement of IL-17 receptor signaling in radiation-resistant cells in the joint for full progression of destructive synovitis. J Immunol 2005, 175:33603368.

134. Cho ML, Kang JW, Moon YM, Nam HJ, Jhun JY, Heo SB, Jin HT, Min SY, Ju JH, Park KS, Cho YG, Yoon CH, Park SH, Sung YC, Kim HY: STAT3 and NF-kappaB signal pathway is required for IL-23-mediated IL-17 production in spontaneous arthritis animal model IL-1 receptor antagonist-deficient mice. J Immunol 2006, 176:5652-5661.

135. Abdollahi-Roodsaz S, Joosten LA, Koenders MI, Devesa I, Roelofs MF, Radstake TR, Heuvelmans-Jacobs M, Akira S, Nicklin MJ, Ribeiro-Dias F, van den Berg WB: Stimulation of TLR2 and TLR4 differentially skews the balance of $T$ cells in a mouse model of arthritis. J Clin Invest 2008, 118:205-216. 